\title{
АНАЛІЗ ОСОБИСТІСНОЇ ТА СИТУАТИВНОЇ ТРИВОЖНОСТІ У ХВОРИХ НА ІШЕМІЧНУ ХВОРОБУ СЕРЦЯ
}

\author{
о. М. Петрущак, I. Я. Криницька \\ Медичний чентр Святої Параскеви, м. Львів \\ ДвнЗ «Тернопільський державний медичний університет \\ імені І. Я. Горбачевського МОЗ Украӥни»
}

У статті викладено сучасні дані щодо визначення рівня особистісної та ситуативної тривожності у хворих на ішемічну хворобу серця у гендерному аспекті. Встановлено, що високий рівень особистісної тривожності $є$ більш характерним для жінок, на відміну від чоловіків, у яких при меншому рівні особистісної тривожності значно переважає тривожність ситуативна.

\section{ANALYSIS OF PERSONAL AND SITUATIVE ANXIETY IN PATIENTS WITH ISCHEMIC HEART DISEASE}

\author{
O. M. Petrushchak, I. Ya. Krynytska \\ Medical center of St. Paraskeva, Lviv \\ I. Horbachevsky Ternopil State Medical University
}

\begin{abstract}
The article presents current data on determination of the level of personal and situational anxiety in patients with coronary heart disease in the gender aspect. It has been established that a high level of personal anxiety is more characteristic of women, unlike men, in which at a lower level of personal anxiety significantly dominates the situational anxiety.
\end{abstract}

Вступ. Ішемічна хвороба серця (IXC) - одна з найактуальніших проблем сучасної кардіології. IXC $\epsilon$ основною причиною захворюваності та смертності серед дорослого населення як у світі, так і в Україні. За статистичними даними, поширеність IXC серед дорослого населення в Україні становить 9 \%. За період 2008-2012 рр. її поширеність серед дорослих поступово збільшувалася (на 6,7 \%) і досягла 24 088,1 особи на 100000 населення, а захворюваність зменшилася на 2,2 \% і становила 1 639,9 особи на 100000 населення. За останній рік кількість хворих зросла на 60332 особи (на 1,0%). Питома вага працездатного населення у структурі поширеності й захворюваності серед усіх дорослих становить, відповідно, 28,9 і 43,9 \%. Це захворювання може призводити до дуже тяжких ускладнень, погіршувати якість життя пацієнта, впливаючи на його працездатність, а також $є$ однією 3 найчастіших кардіальних причин смерті [1-3].

На думку різних авторів, ситуативна і особистісна тривожність напряму пов'язані з ризиком серцево-

(c) О. М. Петрущак, І. Я. Криницька, 2018 судинних захворювань. Основною причиною тривожного синдрому $\epsilon$ тривала заклопотаність або побоювання, що супроводжуються безліччю психомоторних, вегетативних і психічних симптомів і відчуттям нещастя, що наближається. Тривожні очікування людини характеризуються: а) підвищеним збудженням; б) припущенням пацієнта, що майбутні події будуть неконтрольованими і непрогнозованими; в) зміною спрямованості уваги на внутрішні події, пов'язані з хворобою [4].

Мета дослідження - вивчити рівні особистісної та ситуативної тривожності у хворих на ішемічну хворобу серця у гендерному аспекті.

Основна частина. У дослідження було включено 78 пацієнтів, які перебували на амбулаторному лікуванні у Медичному центрі Святої Параскеви, м. Львів.

Умовами відбору до участі у дослідженні були: наявність у хворих встановленого діагнозу IXC, стабільна стенокардія напруги II-III функціонального класу, відсутність в анамнезі інфаркту міокарда та, на момент першого візиту, прогресуючої, нестабільної стенокардії, цукрового діабету та порушення толерантності до 
глюкози згідно з дослідженням рівня глікемії натще після першого візиту, відсутність у хворих вроджених та набутих вад серця і порушення ритму за результатами ЕКГ після першого візиту, злоякісних захворювань та захворювань сполучної тканини в анамнезі. Віковим обмеженням був вік не старше 65 років.

Визначення рівня особистісної та ситуативної тривожності проводили за методикою Ч. Спілбергера в модифікації Ю. Ханіна. Основою цієї методики є двофакторна модель тривожності, що передбачає визначення ії особистісної та ситуативної корелят. як відомо, особистісна тривожність є стійкою індивідуальною властивістю, що характеризує схильність суб'єкта до тривоги та особливості сприйняття різних подразників і реагування на них. Під ситуативною тривожністю розуміють особливості емоційних реакцій людини у відповідь на стресові ситуації, що складають основу формування таких поведінкових реакцій, як нервозність, занепокоєння, напруженість та стурбованість.

Опитувальник Ч. Спілбергера складається з 40 питань-суджень, з котрих 1-20 призначені для оцінки ситуативної тривожності (шкала «Як Ви себе почуваєте на даний момент?») та 21-40 - для визначення особистісної тривожності (шкала «як Ви себе почуваєте зазвичай?»). На кожне запитання можливі 4 відповіді за ступенем інтенсивності (зовсім ні (1 бал), мабуть так (2 бали), правильно (3 бали), цілком імовірно (4 бали))для шкали реактивної тривожності, та 4 відповіді за частотою (майже ніколи (1 бал), іноді (2 бали), часто (3 бали), майже завжди (4 бали)) - для шкали особистісної тривожності.

Показник результату за кожною шкалою може знаходитись в діапазоні від 20 до 80 балів. Чим він більший, тим вищий рівень тривожності (реактивної або особистісної). Оцінка рівнів реактивної та особистісної тривожності за результатами показників здійснюється в таких межах: до 30 балів - низький рівень тривожності, від 31-45 балів - середній, більше 45 балів - високий рівень тривожності.

Шкала «Як Ви себе почуваєте на даний момент?»

1. Я спокійний.

2. Мені нічого не загрожує.

3. Я напружений.

4. Я відчуваю співчуття.

5. Я почуваю себе вільно.

6. Я прикро вражений.

7. Мене хвилюють можливі негаразди.

8. Я почуваюся відпочившим.

9. Я стривожений.
10. Я відчуваю внутрішнє задоволення.

11. Я впевнений у собі.

12. Я нервую.

13. Я не знаходжу собі місця.

14. Я напружений (накручений).

15. Я не відчуваю напруженості, скованості.

16. Я задоволений.

17. Я заклопотаний.

18. Я занадто збуджений і мені ніяково.

19. Мені радісно.

20. Мені приємно.

Шкала «Як Ви себе почуваєте зазвичай?»

21. Я відчуваю задоволення.

22. Я дуже швидко втомлююсь.

23. Я легко можу заплакати.

24. Я хотів би бути таким же щасливим, як й інші.

25. Буває, що я програю через те, що недостатньо швидко приймаю рішення.

26. Я почуваюся бадьорим.

27. Я спокійний, холоднокровний і зібраний.

28. Очікувані труднощі дуже непокоять мене.

29. Я занадто сильно переживаю через дрібниці.

30. Я цілком щасливий.

31. Я приймаю все занадто близько до серця.

32. Мені не вистачає впевненості в собі.

33. Я почуваюся в безпеці.

34. я намагаюся уникати критичних ситуацій i труднощів.

35. У мене буває похмурий настрій.

36. Я задоволений.

37. Всілякі дрібниці відволікають та хвилюють мене.

38. Я так сильно переживаю свої розчарування, що потім довго не можу про них забути.

39. Я врівноважена людина.

40. Мене охоплює сильне занепокоєння, коли я думаю про свої справи та турботи.

При обстеженні хворих за методикою, запропонованою Ч. Д. Спілбергером, адаптованою Ю. Л. Ханіним, було встановлено, що обстежені чоловіки мають високий рівень ситуативної тривожності (54,2 \% респондентів), помірний рівень - 26,8 \% респондентів і низький рівень - 19,0 \% осіб (табл. 1). У жінок рівень ситуативної тривожності набагато менший. При цьому високий рівень особистісної тривожності спостерігали в 58,2 \% обстежених жінок, помірний рівень - 25,9 \% респондентів і низький рівень - 15,9 \% осіб.

Висновки. Високий рівень особистісної тривожності $\epsilon$ більш характерним для жінок, на відміну від 
Таблиця 1. Вираження показників ситуативної й особистісної тривожності у хворих на ішемічну хворобу серця

\begin{tabular}{|l|c|c|}
\hline \multicolumn{2}{|c|}{ Рівень тривожності } & Чоловіки (n=48) \\
\hline \multicolumn{3}{|c|}{ Ситуативна тривожність } \\
\hline Низький & $19,0 \% 30)$ \\
\hline Помірний & $26,8 \%$ & $40,1 \%$ \\
\hline Високий & $54,2 \%$ & $29,5 \%$ \\
\hline \multicolumn{3}{|c|}{ Особистісна тривожність } \\
\hline Низький & $34,4 \%$ & $30,4 \%$ \\
\hline Помірний & $40,5 \%$ & $15,9 \%$ \\
\hline Високий & $25,1 \%$ & $25,9 \%$ \\
\hline
\end{tabular}

чоловіків, у яких при меншому рівні особистісної тривожності значно переважає тривожність ситуативна. Оцінка рівня тривожності дозволяє правильно

\section{СПИСОК ЛІТЕРАТУРИ}

1. Ішемічна хвороба серця, гострий коронарний синдром: ключові положення : тези лекцій / за ред. Ю. М. Мостового, Л. В. Распутіної. - К. : Центр ДЗК, 2017. - 96 с.

2. Новицька А. В. Лікування ішемічної хвороби серця: можливості та переваги метаболічної цитопротекції та ангіопротекції / А. В. Новицька, В. І. Суховатенко // Ліки України. - 2015. - № 9-10. - С. 10-14. оцінити стан хворого та повинна враховуватися при плануванні профілактичних, терапевтичних та реабілітаційних заходів.

3. Гандзюк В. А. Аналіз захворюваності на ішемічну хворобу серця в Україні / В. А. Гандзюк // Український кардіологічний журнал. - 2014. - № 3. - С. 45-52.

4. Дукельський О. О. Психологічні особливості хворих на ішемічну хворобу серця, що перенесли стентування коронарних артерій / О. О. Дукельський // Клінічна медицина. - 2010. - T. XV, № 10 (4). - С. 1-7. 